\title{
Phytoplanktonic primary production modulated by coastal geomorphology in a highly dynamic environment of central Chile
}

\author{
Producción primaria fitoplanctónica modulada por la geomorfología costera en un ambiente \\ altamente dinámico en Chile central
}

\author{
Alvaro T. Palma ${ }^{1}$, Luis A. Henríquez ${ }^{1}$ and F. Patricio Ojeda ${ }^{1}$ \\ ${ }^{1}$ Center for Advanced Studies in Ecology and Biodiversity (CASEB) and Departamento de Ecología, Pontificia Universidad \\ Católica de Chile, Casilla 114-D, Santiago, Chile \\ pojeda@bio.puc.cl
}

\begin{abstract}
Resumen.- La circulación asociada a surgencias costeras tiene un efecto regional sobre la comunidad fitoplanctónica (i.e. aumento de las tasas fotosintéticas, incremento en biomasa), pero su influencia a escalas espaciales locales es menos clara. A una escala local (cientos de metros) y bajo condiciones de surgencia, zonas de retención con altos niveles de producción primaria (PP) tienden a ocurrir en el lado protegido de pequeñas penínsulas inducidas por la orientación, geometría, tamaño y geomorfología general de este tipo de formaciones costeras. Nosotros cuantificamos producción primaria neta (NPP), bruta (GPP), respiración comunitaria (CR) y biomasa (Chl-a) de ensambles naturales de fitoplancton en ambientes costeros de Chile central. El principal objetivo fue determinar un patrón a corto plazo en PP y CR en ambos lados de dos pequeñas penínsulas en Chile central, donde son esperables diferencias mensurables en varias variables ambientales. Nuestra hipótesis de trabajo es que estas diferencias no ocurren bajo condiciones de relajación o de no-surgencia. Los resultados indican que NPP, GPP y CR difieren a una escala local y, contrariamente a lo reportado previamente, encontramos que el debilitamiento de los vientos favorables a las surgencias pueden generar un patrón opuesto a lo observado durante un periodo activo de surgencia, donde el sitio expuesto retiene altas concentraciones de biomasa y exhibe elevados niveles de PP comparados con el sitio protegido. Nuestros resultados destacan la importancia de la variabilidad a corto plazo de PP y CR y su acople con la distribución y abundancia del fitoplancton y su rápida respuesta a una escala espacial local.
\end{abstract}

Palabras clave: Oceanografía costera, surgencia, biomasa fitoplanctónica, flujo de carbono, morfología costera

\begin{abstract}
Coastal upwelling circulation has a regional fertilizing effect upon phytoplanktonic communities (i.e. enhancement of photosynthetic rates, increased biomass), but its influence at smaller spatial and temporal scales is less clear. At local scale (100's m) and under upwelling-favorable conditions, retention zones with higher primary production (PP) levels tend to occur at the lee or protected side of small headlands induced by the orientation, geometry, size and general geomorphology of these coastal formations. Here we quantified net and gross primary production (NPP and GPP), community respiration (CR) and biomass (Chl- $a$ ) of natural phytoplankton assemblages in coastal environments of central Chile. The main goal was to determine short-term patterns in PP and CR around two small peninsulas in central Chile where measurable differences in several environmental variables can be expected, and we hypothesize that differences will no longer occur under non-upwelling/relaxation conditions. Results indicate that NPP GPP and CR differ at local scale, and contrary to previous findings we found that weakening of upwelling-favorable winds can generate an opposite pattern to that observed under active upwelling periods, whereas the exposed site retains higher biomass and exhibits higher PP levels compared to the protected site. Our results highlight the importance of short-term variability in PP, CR and their coupling with the distribution and abundance of the quick-responding phytoplankton at local spatial scale.
\end{abstract}

Key words: Nearshore oceanography, upwelling, phytoplanktonic biomass, carbon flux, coastal morphology

et al. 2000, Alcaraz et al. 2002). The role of the coastal zone in the carbon cycling, as well as its trophic status, is still a matter of debate (Gattuso et al. 1998, Duarte et al. 2005), partly due to large differences between proximal and distal parts of the coastal ocean and the lack of a typology, which would enable extension of the data from a local scale to more regional and global scales (Bensoussan \& Gattuso 2007). 
The rate at which this PP occurs in very near shore coastal settings has been scarcely quantified and very few studies have focused their attention on the short-term variability in PP, CR and on distribution and abundance of phytoplanktonic biomass (Chl- $a$ ) at scales ranging from hundreds of meters to few kilometers (but see Henríquez et al. 2007). Measuring the rate of evolution of oxygen produced, the prime methodology used in the present study is a widely used approach for estimating gross primary production (GPP), net primary production (NPP) and community respiration (CR) in coastal waters and has allowed estimations of carbon flux in these environments (Macedo et al. 1998, Daneri et al. 2000, York et al. 2001, Hashimoto et al. 2005, Cermeño et al. 2006).

Quantifying very nearshore hydrographic variables likely to affect the distribution of both inorganic nutrients and phytoplankton under different conditions such as upwelling, retention, and advection of water masses allows a better understanding of how phytoplankton does interact with the environment in a moving parcel of water (i.e. Lagrangian frame). Along the coast of central Chile, elevated levels of PP and Chl- $a$ concentrations are common during upwelling events owing to the action of southerly and south-westerly winds that favor these advective events during spring and summer months by causing intermittent upwellings and relaxations over periods ranging from 3 to 10 days (Daneri et al. 2000, Poulin et al. 2002). These events have been considered responsible for the occurrence of phytoplankton-rich patches of waters masses off Chile (Marín et al. 1993).

Another important factor that affects the distribution and the amount of PP and Chl- $a$ is the interaction of coastal geomorphology with nearshore circulation processes (Signell \& Geyer 1991, Wing et al. 1998, Pawlak et al. 2003, Gan et al. 2004, Roughan et al. 2005a, Mace \& Morgan 2006). From local to regional scales, several studies agree that geomorphological factors may influence the occurrence of coastal fronts or the presence of nearshore retention zones that may modify patterns of aggregation and transport of benthic invertebrate larvae (Wing et al. 1998, Archambault \& Bourget 1999, Botsford 2001, Poulin et al. 2002, Palma et al. 2006) and furthermore, geomorphological factors influence the distribution of phytoplankton biomass and production (Archambault et al. 1999, Shanks \& McCulloch 2003, Henríquez et al. 2007).

At a local scale (100's m), and under upwellingfavorable conditions, conspicuous retention zones with higher levels of phytoplanktonic primary production were found to occur at lee or protected sides of small headlands or little peninsulas, induced by topographic features, orientation, geometry, size and depth of these type of coastal geomorphological formations (Roughan et al. 2005b, Palma et al. 2006, Henríquez et al. 2007). Then, we hypothesize that such features will cease to occur, and even revert, under non-upwelling/relaxation conditions.

The main objective of this study was to determine short-term spatial patterns in phytoplanktonic production and community respiration at the exposed and protected sites on two peninsulas along the central coast of Chile where measurable differences in several environmental variables (i.e. wind pattern and its effect on local circulation) occur at small spatial scales.

\section{Material and methods}

\section{Sampling}

The study was carried out in the coastal zone of central Chile, on the Punta de Tralca Peninsula (TP; $33^{\circ} 25^{\prime}$ S; $\left.71^{\circ} 43^{\prime} \mathrm{W}\right)$. Surveys were scheduled in order to characterize the variability of the system over short periods of time (weeks) during the austral summer of 2006. In addition, during the summer of 2007 two surveys were performed on the Quintay Peninsula located ca. 25 $\mathrm{km}$ to the north of TP (QP; $33^{\circ} 18^{\prime} \mathrm{S}$; $\left.71^{\circ} 42^{\prime} \mathrm{W}\right)$ as well as on the TP. Each location (peninsula) was composed of two sites, one at the exposed and one at the protected side of each peninsula (Fig. 1). All weekly water column samples were collected before midday from each site. Both surface ( $0.5 \mathrm{~m}$ depth) and subsurface (5, 10 and 18 $\mathrm{m}$ depth) water samples were collected using a 5-L PVC Niskin bottle and transported to the laboratory in individually labeled black plastic containers inside portable coolers. The collecting process at each site lasted less than $30 \mathrm{~min}$ after which the other site was visited before 5 minutes.

\section{Local environmental variables}

During every weekly visit to TP the properties of the water column were characterized (temperature, dissolved oxygen and Chl- $a$ ) using a CTD (Seabird 19, equipped with Wetstar miniature fluorometer and SBE 23 oxygenmeter). Moreover, temperature of the water column was recorded at the protected site on TP every $10 \mathrm{~min}$ at the surface (-1 $\mathrm{m})$ and at the bottom (-20 $\mathrm{m}$ ) using temperature loggers (Stow Away Tidbits, Onset Computer Corp.; precision level $\pm 0.3^{\circ} \mathrm{C}$ ) attached to a permanent mooring line allowing us to quantify the degree of stratification of the water column. A time series of wind speed and direction, measured one datum every 10 minutes, was obtained from a meteorological station (HOBO Micro 


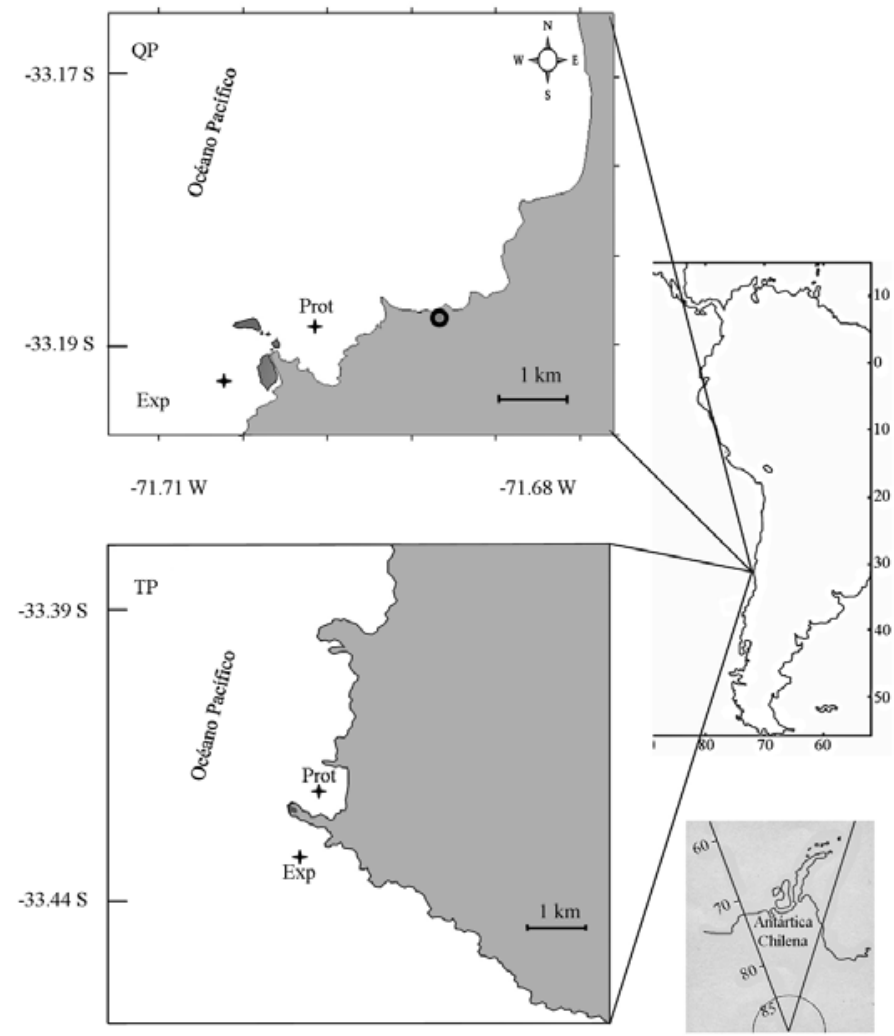

Figure 1

Map of the two study locations, Quintay peninsula (QP) and Punta de Tralca peninsula (TP) located in central Chile. Sites within each location are identified as (Prot) protected and (Exp) exposed. Circle indicates location of meteorological microstation. The depth at each site is $25 \mathrm{~m}$

Mapa de las dos localidades de estudio, península Quintay (QP) y península Punta de Tralca (TP) ubicadas en Chile central. Los sitios en cada localidad son identificados como (Prot) protegido y (Exp) expuesto. El círculo indica la ubicación de la micro estación meteorológica. La profundidad de cada sitio es de $25 \mathrm{~m}$

Station, Onset Computers Corp.) located near the QP (Fig. 1). At each site and while water samples were collected, the light attenuation depth was estimated using a Secchi disk (known as Secchi depth). For the determination of Chl- $a$ concentration one liter of seawater from each sample was filtered through a Whatman GF/F glass filter using a manual pump (Advantec MFS, Inc. KP $47 \mathrm{~S}$ ). The filters were then wrapped in aluminum foil and stored at $-20^{\circ} \mathrm{C}$. Within a week pigments were extracted in $90 \%$ acetone for $24 \mathrm{~h}$ at $0^{\circ} \mathrm{C}$ in complete darkness. The absorbance of the extract was read on a spectrophotometer (HACH DR 2700, Germany). The concentration of inorganic nutrients $\left(\mathrm{NO}_{2}{ }^{-}\right.$and $\left.\mathrm{NO}_{3}{ }^{-}\right)$were determined in surface seawater samples during the summer of 2006 and in samples collected at discrete depths (0, 5, 10 and $18 \mathrm{~m})$ during the summer of 2007 using the standard methodology described by Parsons et al. (1984).

\section{Community photosynthesis and respiration}

Gross primary production (GPP), net primary production (NPP) and community respiration (CR) were determined in surface water samples during the summer 2006 from in vitro changes in dissolved oxygen after light and dark bottle incubations using Winkler methodology (Strickland \& Parsons 1972, Macedo et al. 1998, Cermeño et al. 2006, Henríquez et al. 2007). The water samples were dispensed into 125-mL borosilicate bottles through a silicon hose placed at the bottom of each bottle in order to keep turbulence to a minimum. Fifteen $125 \mathrm{~mL}$ (5 initial, 5 light and 5 dark) bottles (for each site, exposed and protected) were carefully filled from each carboy by 
(a)

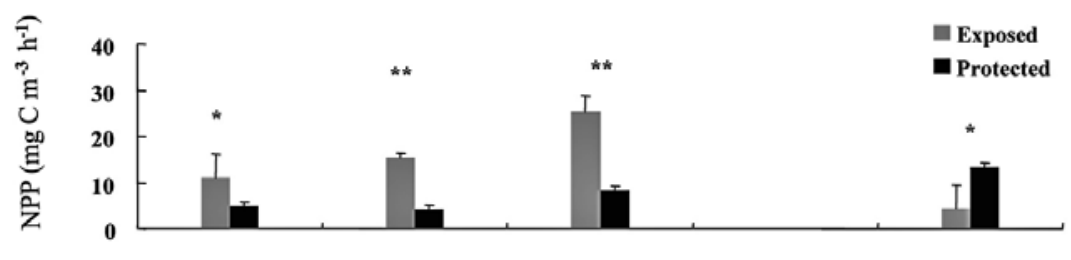

(b)

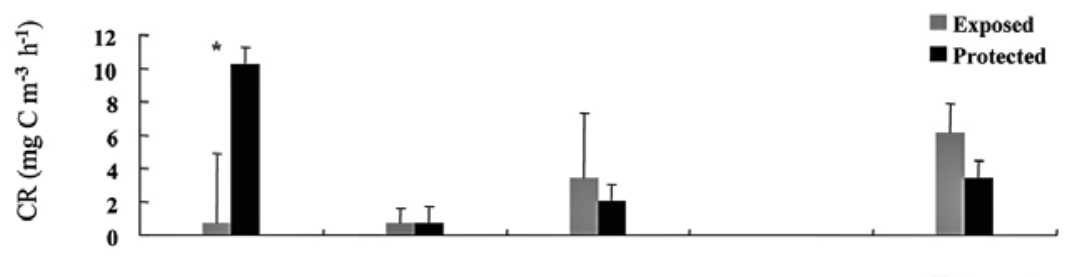

(c)

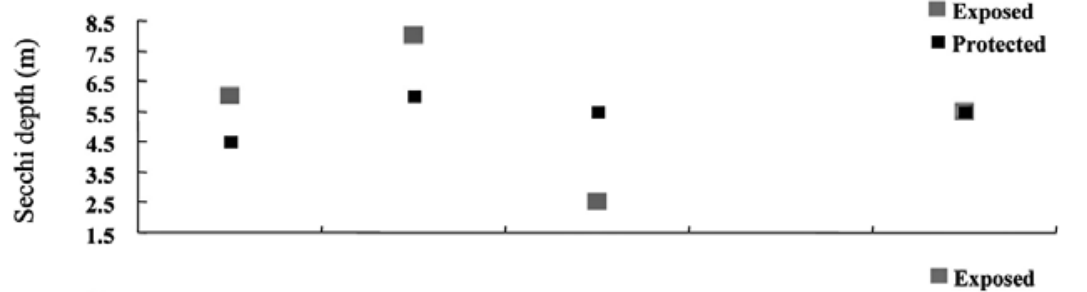

(d)

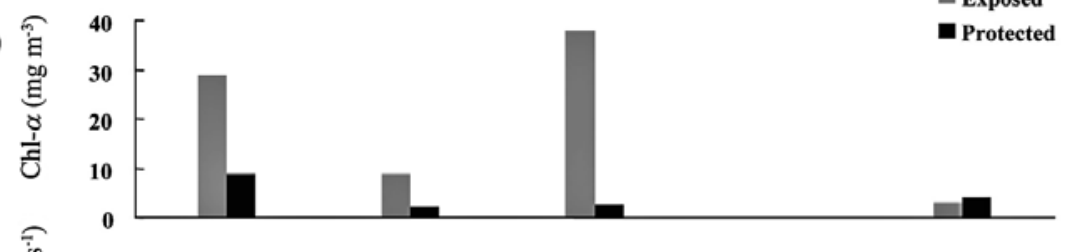

(e)

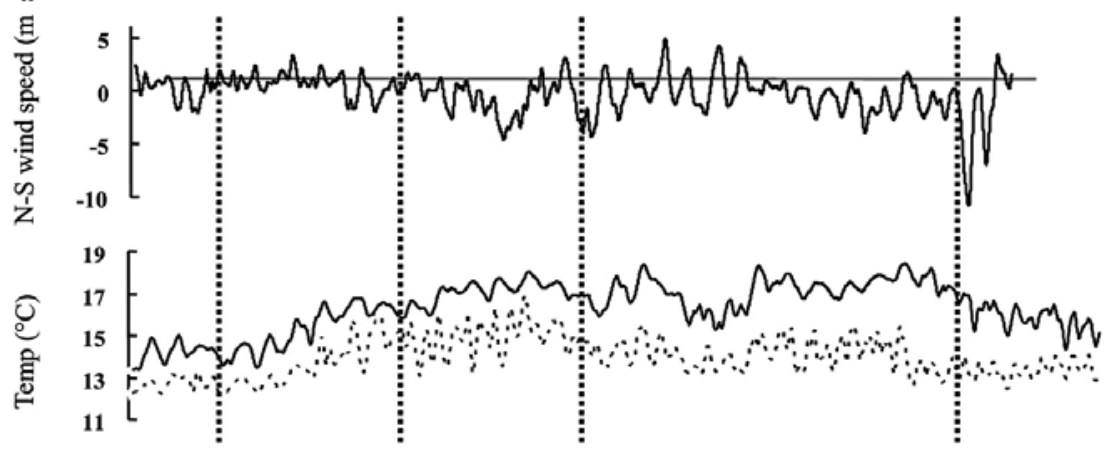

24 Jan $31 \mathrm{Jan} \quad 7 \mathrm{Feb} 22 \mathrm{Feb}$

Figure 2

Weekly variation of: (a) NPP (mg C m$\left.{ }^{-3} \mathrm{~h}^{-1}\right)$, (b) CR (mg C m${ }^{-3} \mathrm{~h}^{-1}$ ), (c) Secchi depth (m), (d) Chl-a (mg m ${ }^{-3}$ ), (e) North-South wind speed $\left(\mathrm{ms}^{-1}\right)$ component (negative values indicate wind from the south) and (f) Short-time series of temperature $\left({ }^{\circ} \mathrm{C}\right)$ at the protected sites of TP between January and February 2006. Dashed and continuous lines in (f) represent bottom and surface temperatures, respectively. $* P<0.05$ and $* * P<0.001$. Vertical lines indicate days when water samples were obtained

Variación semanal de: (a) NPP (mg C m ${ }^{-3} \mathrm{~h}^{-1}$ ), (b) CR (mg C m ${ }^{-3} \mathrm{~h}^{-1}$ ), (c) profundidad Secchi (m), (d) Chl- $a$ (mg m ${ }^{-3}$ ), (e) velocidad de la componente del viento Norte-Sur $\left(\mathrm{ms}^{-1}\right.$ ) (valores negativos indican que el viento proviene desde el sur) y (f) serie de tiempo de temperatura $\left({ }^{\circ} \mathrm{C}\right.$ ) en el sitio protegido de TP entre enero y febrero de 2006. Líneas punteadas y continuas representan temperaturas a $20 \mathrm{~m}$ y en superficie, respectivamente. ${ }^{*} P<0,05$ y $* * P<0,001$. Líneas verticales indican los días cuando se 
means of silicon hose overflowing (>350 mL) and taking precautions to minimize sample exposure to light. Five bottles were fixed immediately for initial determination of oxygen concentration, five dark and five light bottles were incubated in containers with a continuous flow of water (in order to keep temperature down) for a period of $6 \mathrm{~h}$ under two-500 W halogen lamps simulating midday light intensity. The same methodology was used during the summer of 2007, for water samples obtained at different depths, except for light and dark bottles were incubated in situ at those depths (0, 5, 10 and $18 \mathrm{~m})$ from sunrise to dusk attached to the mooring lines located at the exposed and protected sites on TP and QP. This made it possible to obtain depth-integrated values of GPP, NPP and CR. Dissolved oxygen was quantified via titration using an automated burette (Digitrate Pro50 ml Jencons, UK). Production and respiration rates were calculated as follows: $\mathrm{NPP}=\Delta \mathrm{O}_{2}$ in light bottles (mean of $\left[\mathrm{O}_{2}\right]$ in $6 \mathrm{~h}$ light bottles - mean of initial $\left[\mathrm{O}_{2}\right]$ bottles); $\mathrm{CR}=\Delta \mathrm{O}_{2}$ in dark bottles (mean of initial $\left[\mathrm{O}_{2}\right]$ bottles - mean of $\left[\mathrm{O}_{2}\right]$ in $6 \mathrm{~h}$ dark bottles); GPP $=\mathrm{NPP}+\mathrm{CR}$. The oxygen concentration was converted to carbon units using a photosynthetic quotient for Chilean coastal waters of 1.25 (Daneri et al. 2000).

\section{Statistical analyses}

Weekly values of NPP and CR at the exposed and protected sites at TP were compared using one-way ANOVAs. In all cases, the data were logarithmically transformed to meet the assumptions of normality and homogeneity of variances. The residues were analyzed with Cochran's test (Zar 1999). All the tests were made using the statistical package Statistica (version 6.0) considering a $95 \%$ confidence interval throughout this study.

\section{Results}

\section{Punta de Tralca Peninsula (TP): Summer 2006}

\section{Weekly samples: surface net primary production (NPP) and community respiration (CR)}

The magnitudes of NPP at the exposed and protected sites were significantly different with higher values at the exposed site, except on February 22 when the protected site exhibited particularly higher values (Fig. 2a). The only significant difference for CR corresponded to higher values of this variable at the protected site on January 24 (Fig. 2b).

\section{Weekly samples: local environmental variables}

During the period between January 24 to February 22 the total phytoplankton biomass (Chl-a) collected at the surface was higher at the exposed site, reaching its maximum value of $37.82 \mathrm{mg}$ Chl- $a \mathrm{~m}^{-3}$ on February 7. Only on February 22 the Chl- $a$ values were higher at the protected site than the values measured at the exposed site (4 and 3.11 Chl- $a^{-3}$, respectively) (Fig. 2d). The water column temperature time-series, only measured at the protected site, exhibited a difference between the surface and the bottom (25 m), even more so toward the end of the series (Fig. 2f), when stratification was more evident. The prevailing southerly breeze exhibited little variation during the first half of the time series and started to become more intense toward the second half of the series. By February 22 southerly winds increased to the maximum value observed during the recorded period (Fig. $2 \mathrm{e})$. The Secchi depth was greater at the exposed site on January 24 and 31, whereas on February 7 the higher values were measured at the protected site while on February 22 the values were similar (5.5 m) (Fig. 2c). Additionally, the fluorescence profiles (index of phytoplanktonic biomass Chl- $a \mathrm{mg} \mathrm{L}^{-1}$ ) obtained with the CTD showed a homogeneous water column except on February 7, when a subsurface chlorophyll maximum (SCM) at a depth of ca. $6 \mathrm{~m}$ was detected at the exposed site (Fig. 3a). Vertical temperature profiles illustrated two particular hydrographic conditions typified by (a) formation of distinctly different thermocline layers at two sites and (b) in February, a thermally homogenous water column at both sites with little temperature differences between sites (Fig. 3b). The amount of dissolved oxygen in the water column was highly variable and exhibited notorious differences between sites only on January 24 and on February 7 (Fig. 3c). Table 1 shows a summary of the values for surface NPP, CR, Chl- $a$, Secchi depth and inorganic nutrients concentrations $\left(\mathrm{NO}_{2}\right.$ and $\mathrm{NO}_{3}$ concentrations were only measured in February).

\section{Surface NPP and Chl- $a$ relationship}

A significant linear correlation was found between Chl$a$ and NPP (Fig. 4) when we pooled all NPP and Chl- $a$ data for PT, without considering sites separately.

\section{Daily integrated shallow water column: summer 2007}

Table 2 shows the depth-integrated values of GPP, NPP, $\mathrm{CR}$, Chl- $a$ and inorganic nutrients $\left(\mathrm{NO}_{2}\right.$ and $\left.\mathrm{NO}_{3}\right)$ in a shallow water column $(<25 \mathrm{~m})$ in the QP and TP in January 17 and February 13, 2007, respectively. The protected site at QP exhibited higher values for all these variables except Chl- $a$ (1.14 and $7.86 \mathrm{mg} \mathrm{m}^{-2}$ at the 
a) Chl- $a\left(\mathrm{mg} \mathrm{L}^{-1}\right)$

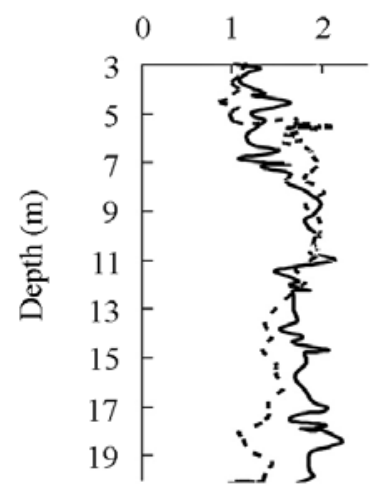

b)

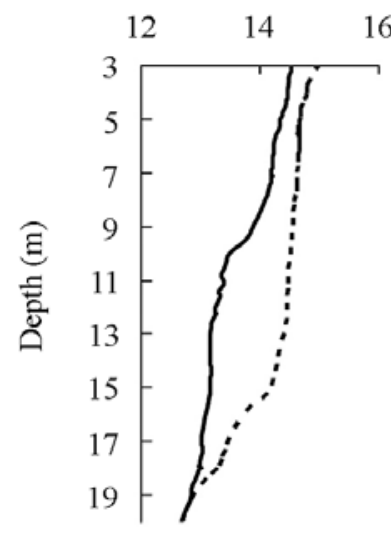

c)

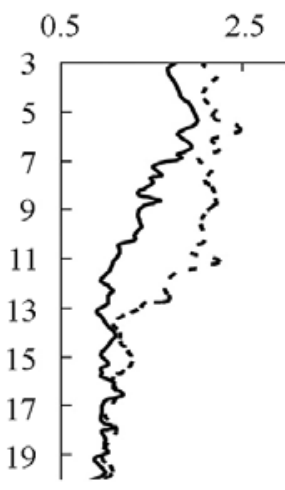

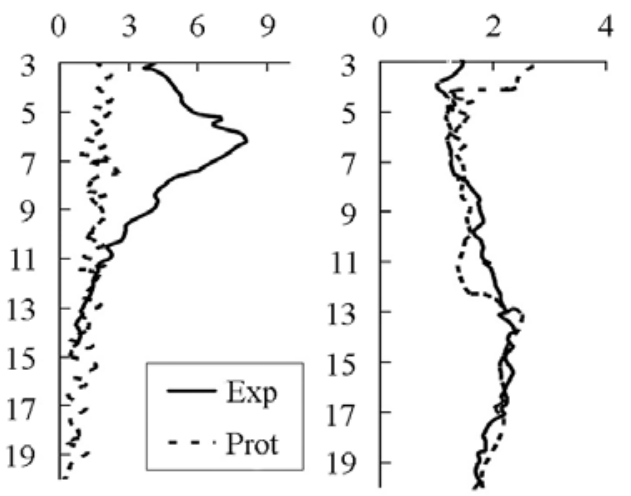

Temperature $\left({ }^{\circ} \mathrm{C}\right)$

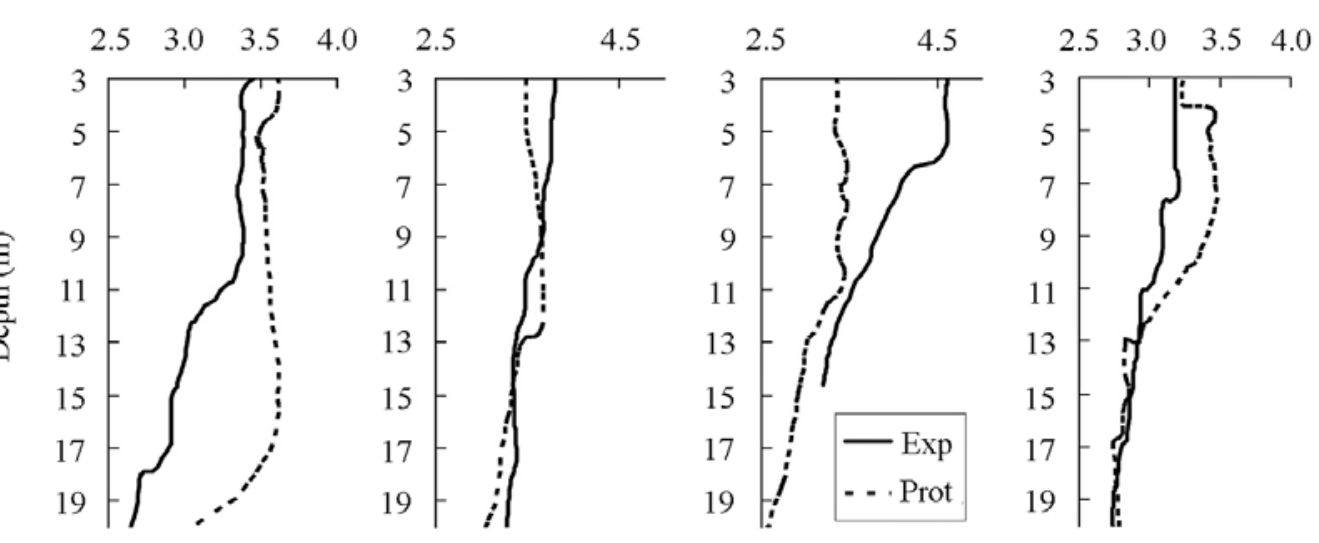

Figure 3

Vertical profiles of: (a) Index of phytoplankton biomass Chl-a $\left(\mathrm{mg} \mathrm{L}^{-1}\right)$, (b) Temperature $\left({ }^{\circ} \mathrm{C}\right)$ and $(\mathrm{c})$ Oxygen $\left(\mathrm{mg} \mathrm{L}^{-1}\right)$ at the Exposed (continuous line) and Protected (dashed line) at the TP

Perfiles verticales de: (a) Índice de biomasa fitoplanctónica Chl- $a\left(\mathrm{mg} \mathrm{L}^{-1}\right)$, (b) Temperatura $\left({ }^{\circ} \mathrm{C}\right)$ y (c) Oxígeno (mg L $\left.{ }^{-1}\right)$ en el sitio Expuesto (línea continua) y Protegido (línea punteada) en la TP 
Table 1

Summary data of weekly variation at protected and exposed sites during the summer of 2006 at Punta de

Tralca peninsula. Values of NPP and CR exhibit the average and standard deviation (s.d.).

Chl-a, Secchi depth and inorganic nutrients $\mathrm{NO}_{2}$ and $\mathrm{NO}_{3}$ correspond to a single value

Resumen de los resultados de la variación semanal en los sitios protegidos y expuestos durante el verano de 2006 en la península de Punta de Tralca. Valores de NPP y CR muestran el promedio y la desviación estándar (s.d.).

Chl- $a$, profundidad Secchi y nutrientes inorgánicos $\mathrm{NO}_{2}$ y NO 3 corresponden a un solo valor

\begin{tabular}{|c|c|c|c|c|c|c|c|c|c|c|c|c|}
\hline \multirow[t]{2}{*}{ Date } & \multicolumn{6}{|c|}{ Protected } & \multicolumn{6}{|c|}{ Exposed } \\
\hline & NPP & CR & Chl- $a$ & Secchi & $\mathrm{NO}_{2}$ & $\mathrm{NO}_{3}$ & NPP & CR & Chl- $a$ & Secchi & $\mathrm{NO}_{2}$ & $\mathrm{NO}_{3}$ \\
\hline 24 Jan & $4.78(5.18)$ & $10.24(4.18)$ & 8.9 & 4.5 & n.d & n.d & $10.93(1.53)$ & $0.68(2.56)$ & 28.9 & 6 & n.d & n.d \\
\hline 31 Jan & $4.10(0.94)$ & $0.68(0.94)$ & 2.22 & 6 & n.d & n.d & $15.36(2.41)$ & $0.68(1.53)$ & 8.9 & 8 & n.d & n.d \\
\hline $7 \mathrm{Feb}$ & $8.19(3.5)$ & $2.05(3.89)$ & 2.5 & 5.5 & 0.43 & 8.1 & $25.27(4.25)$ & $3.41(4.68)$ & 37.82 & 2.5 & 0.06 & 14.1 \\
\hline $22 \mathrm{Feb}$ & $13.32(4.89)$ & $3.41(1.71)$ & 4 & 5.5 & 0.49 & 10.7 & 4.44 (1.99) & $6.15(2.86)$ & 3.11 & 5.5 & 0.44 & 6.3 \\
\hline
\end{tabular}

Note: NPP and CR (mg C m$\left.{ }^{-3} \mathrm{~h}^{-1}\right) ; \mathrm{Chl} a\left(\mathrm{mg} \mathrm{m}^{-3}\right)$; Secchi depth (m); $\mathrm{NO}_{2}$ and $\mathrm{NO}_{3}(\mu \mathrm{M})$.

Table 2

Daily integrated values of gross primary production (GPP), net primary production (NPP), community respiration (CR), phytoplanktonic biomass (Chl-a) and inorganic nutrients during the summer of 2007 at the exposed and protected sites of QP and TP

Valores integrados diarios de producción primaria bruta (GPP), producción primaria neta (NPP), respiración comunitaria (CR), biomasa fitoplanctónica (Chl-a) y nutrientes inorgánicos durante el verano de 2007 en los sitios protegido y expuesto de QP y TP

\begin{tabular}{|c|c|c|c|c|c|c|c|c|c|c|c|c|}
\hline \multirow[t]{2}{*}{ Date/locality } & \multicolumn{6}{|c|}{ Protected } & \multicolumn{6}{|c|}{ Exposed } \\
\hline & GPP & NPP & $\mathrm{CR}$ & Chl- $a$ & $\mathrm{NO}_{2}$ & $\mathrm{NO}_{3}$ & GPP & NPP & $\mathrm{CR}$ & Chl- $a$ & $\mathrm{NO}_{2}$ & $\mathrm{NO}_{3}$ \\
\hline QP 17 Jan & 83.51 & 51.35 & 32.16 & 1.14 & 0.04 & 1.32 & 64.68 & 44.38 & 20.30 & 7.86 & 0.02 & 0.87 \\
\hline TP 13 Feb & 12.91 & 4.9 & 8.01 & 3.88 & 0.033 & 1.21 & 13.65 & 2.57 & 11.08 & 2.28 & 0.039 & 0.71 \\
\hline
\end{tabular}

Note: GPP, NPP and $\mathrm{CR}\left(\mathrm{mg} \mathrm{C} \mathrm{m}^{-3} \mathrm{~h}^{-1}\right) ; \mathrm{Chl} a\left(\mathrm{mg} \mathrm{m}^{-2}\right) ; \mathrm{NO}_{2}$ and $\mathrm{NO}_{3}(\mu \mathrm{M})$.

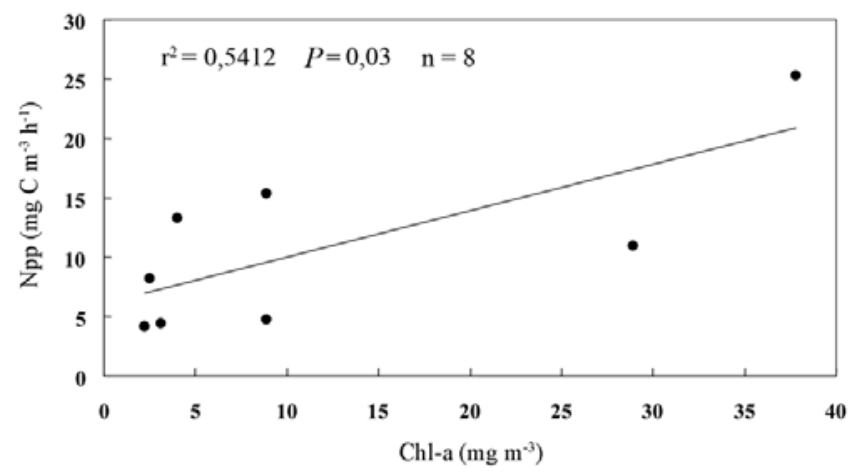

Figure 4

Relationship between NPP $\left(\mathrm{mg} \mathrm{C} \mathrm{m}^{-3} \mathrm{~h}^{-1}\right)$ and Chl- $a\left(\mathrm{mg} \mathrm{m}^{-3}\right)$, showing regression coefficient $\left(\mathrm{r}^{2}\right)$, probability $(P)$ and the number of data used (n)

Relación entre NPP $\left(\mathrm{mg} \mathrm{C} \mathrm{m}^{-3} \mathrm{~h}^{-1}\right)$ y Chl- $a\left(\mathrm{mg} \mathrm{m}^{-3}\right)$, mostrando el coeficiente de regresion $\left(\mathrm{r}^{2}\right)$, la probabilidad $(P)$ y el número de datos usados (n) 
protected and exposed site respectively). However, in the TP on February 13, 2007 the GPP and CR values were higher at the exposed site but the NPP and Chl- $a$ were higher at the protected site. $\mathrm{NO}_{3}$ concentrations were higher at the protected sites but $\mathrm{NO}_{2}$ was higher at the QP on January 7 and at TP on February 13 have a similar concentration.

\section{Discussion}

Measurement of phytoplanktonic primary productionrelated variables (e.g. wind, temperature and Secchi depth), performed on nearby sites on opposite sides of small peninsulas, showed how their magnitudes can exhibit important differences at these scales. However, and as stated in our working hypothesis, our results obtained in a context of exposed and protected shores exhibited differences that appear to show important variations depending on the prevailing hydrographic conditions at the time of data collection.

The weekly variation in PP values was significantly higher at the exposed site of TP, mainly during the first three surveys when greater Chl- $a$ concentrations (Fig. $2 \mathrm{a}$ and $\mathrm{d}$ ) were measured. At this location CR only exhibited significant differences between sites during the first survey, with values at the protected site twice as those for NPP registered at the same site (Fig. 2b).

The continuous record of surface and bottom temperature measured at the protected site of TP showed the presence of a continuously stratified water column during the whole period, however, there was an evident warming of the whole water column during January that reached its maximum temperature during February of 2006. This pattern was local and it could have been a result of the prevailing weak wind conditions since the cooling of water column begun as a result of the southerly wind that started blowing days before February 22 (Fig. 2e and f). During the first two surveys we detected a shallower thermocline in the exposed site of TP, which coincided with the local warming of the water column (Fig. 3b). However, only on February 7 the Chl-a profile revealed a shallow subsurface chlorophyll maximum at $6 \mathrm{~m}$ below the surface, concurrent with the occurrence of highest PP levels in a well-oxygenated shallow water column (Fig. 3a and c). As the system we studied and in other upwelling dominated coastal systems (Daneri et al. 2000, Montecino \& Quiroz 2000, Cermeño et al. 2006) primary production is mainly supported by the existing autotrophic phytoplankton biomass and is clearly depicted by the positive and significant relationship between NPP and Chl- $a$ (Fig. 4).
During the summer of 2007 the PP of the water column was integrated down to $20 \mathrm{~m}$ in the exposed and protected sites on January 17 at QP and on February 13 at TP. We observed that PP was greater at the protected site of each peninsula, however, it is worth highlighting that the values for CR were greater than those of NPP at TP on both dates. Additionally, and considering that PP is proportional to the amount of phytoplanktonic biomass, when we integrated Chl- $a$ in QP we observed that when Chl- $a$ was low PP was high, whereas in TP the high concentration of Chl- $a$ did not result in an increment of PP (Table 2). These results allow discussing on the physiological status of the phytoplanktonic community present in the water column. Low concentrations of phytoplanktonic biomass (Chl-a) would be able to fix carbon in a more efficient way given that there is no competition for limiting resources such as nutrients and light (Ploug et al. 1999, Garget \& Marra 2002). The observed patterns could also be explained by the fact that bacterial activity in coastal waters, affected by seasonal upwelling and downwelling conditions, is high, which could then explain why in some cases the CR rises above the PP (Cuevas et al. 2004).

In highly dynamic coastal systems where circulation and wind regimes interact with the local geomorphology it is possible to identify sites with higher retention of phytoplanktonic biomass (Roughan et al. 2005a, Mace \& Morgan 2006, Henríquez et al. 2007). In our case, and during normal summer conditions, the wind typically comes from the south and south west with magnitudes that generate coastal upwelling events which in turn promote high levels of primary production (Daneri et al. 2000, Poulin et al. 2002). It has been shown that during upwelling periods, protected sites exhibit high retention of phytoplanktonic biomass (Henríquez et al. 2007). However, in the present study we observed how the weakening of the upwelling-favorable winds can generate an opposite pattern to that described by Henríquez et al. (2007) whereas the exposed sites retains more phytoplanktonic biomass and exhibited higher levels of PP than the protected sites. A similar pattern was described by Vander Woude et al. (2006), whom noticed elevated chlorophyll concentrations in retentive zones adjacent to headlands during upwelling-favorable wind conditions which highlights the importance of short-term variability in PP, CR and on distribution and abundance of phytoplanktonic biomass at a local spatial scale. Further, our contrasting results, compared to other studies (e.g. Vander Woude et al. 2006 and Henríquez et al. 2007), conducted in similar scenarios but under nonupwelling conditions, points out to the need of better understanding coastal circulation and its effect upon the 
variability of important biological components like phytoplankton under a variety of oceanographic conditions.

\section{Acknowledgments}

We want to thank the enthusiastic field assistance of F. Ogalde and the additional equipment provided by G. Daneri. We are particularly thankful of the important and thorough review made by three anonymous reviewers. This research was made possible by the financial support of FONDAP grant $N^{\circ} 1501-0001$ program 5 and 2 to the Center for Advanced Studies in Ecology and Biodiversity (CASEB).

\section{Literature cited}

Alcaraz M, F Marrasé, F Peters, L Arin \& A Malits. 2002. Effects of turbulence conditions on the balance between production and respiration in marine planktonic communities. Marine Ecology Progress Series 242: 63-71.

Archambault P \& E Bourget. 1999. Influence of shoreline configuration on spatial variation of meroplanktonic larvae, recruitment and diversity of benthic subtidal community. Journal of Experimental Marine Biology and Ecology 238: 161-184.

Archambault P, CW McKinsey \& E Bourget. 1999. Largescale shoreline configuration influences phytoplankton concentration and mussel growth. Estuarine Coastal and Shelf Science 49: 193-208.

Bensoussan N \& JP Gattuso. 2007. Community primary production and calcification in a NW Mediterranean ecosystem dominate by calcareous macroalgae. Marine Ecology Progress Series 334: 37-45.

Botsford LW. 2001. Physical influences on recruitment to California Current invertebrate population on multiple scales. Journal of Marine Science 58: 1081-1091.

Cermeño P, E Marañon, V Pérez, P Serret, E Fernández \& C Castro. 2006. Phytoplankton size structure and primary production in a highly dynamic coastal ecosystem (Ría de Vigo, NW-Spain): Seasonal and short-term scale variability. Estuarine Coastal and Shelf Science 67: 251-266.

Cuevas L, G Daneri, B Jacob \& P Montero. 2004. Microbial abundant and activity in the seasonal upwelling area off Concepción $\left(\sim 36^{\circ} \mathrm{S}\right)$, central Chile: a comparison of upwelling and no-upwelling condition. Deep Sea Research II 51: 2427-2440.

Daneri G, V Dellarosa, R Quiñones, B Jacob, P Montero \& O Ulloa. 2000. Primary production and community respiration in the Humboldt Current System off Chile and associated oceanic areas. Marine Ecology Progress Series 197: 41-49.

Duarte CM, JJ Middelburg \& N Caraco. 2005. Major role of marine vegetation on the oceanic carbon cycle. Biogeosciences 2: 1-8.
Gan J, RG Ingram, RJ Greatbatch \& T van der Baaren. 2004. Variability of circulation induced by the separation of Gaspe current in Baie de Chaleurs (Canada): observational studies. Estuarine Coastal and Shelf Science 61: 393-402.

Gattuso JP, M Frankignoulle \& R Wollast. 1998. Carbon and carbonate metabolism in coastal aquatic ecosystem. Annual Review of Ecology and Systematics 29: 405-434.

Garget A \& J Marra. 2002. Effects of upper ocean physical processes (Turbulence, Advection and Air-Sea interaction) on oceanic primary production. In: Robinson A, J McCarthy \& B Rothschild (eds). The Sea, Vol. 12: 19-49. John Wiley \& Sons, New York.

Hashimoto S, N Horimoto, Y Yamaguchi, T Ishimaru \& T Saino. 2005. Relationship between net and gross primary production in the Sagami Bay, Japan. Limnology and Oceanography 50: 1830-1835.

Henríquez LA, G Daneri, CA Muñoz, P Montero, R Veas \& AT Palma. 2007. Primary production and phytoplanktonic biomass in shallow marine environments of central Chile: Effect of coastal geomorphology. Estuarine Coastal and Shelf Science 73: 137-147.

Mace AJ \& SG Morgan. 2006. Larval accumulation in the lee of the small headland: implications for the design of marine reserves. Marine Ecology Progress Series 318: 19-29.

Macedo MF, JG Ferreira \& P Duarte. 1998. Dynamic behaviour of photosynthesis-irradiance curves determined from oxygen production during variable incubation periods. Marine Ecology Progress Series 165: 31-43.

Marín V, L Rodríguez, L Vallejo, J Fuenteseca \& E Oyarce. 1993. Efectos de la surgencia costera sobre la productividad primaria primaveral de Bahía Mejillones del Sur (Antofagasta, Chile). Revista Chilena de Historia Natural 66: 479-491.

Moncoiffé G, XA Alvarez-Salgado, FG Figueiras \& G Savidge. 2000. Seasonal and short-time-scale dynamics of microplankton community production and respiration in an inshore upwelling system. Marine Ecology Progress Series. 196: 111-126.

Montecino V \& D Quiroz. 2000. Specific primary production and phytoplankton cell size structure in an upwelling area off the coast of Chile ( $\left.30^{\circ} \mathrm{S}\right)$. Aquatic Science 62: 364380.

Palma AT, LM Pardo, R Veas, C Cartes, M Silva, K Manríquez, A Díaz, C Muñoz \& FP Ojeda. 2006. Coastal brachyuran decapods: settlement and recruitment under contrasting coastal geometry condition. Marine Ecology Progress Series 316: 139-153.

Parsons TR, Y Maita \& CM Lalli. 1984. A manual of chemical and biological methods for seawater analysis, 184 pp. Pergamon Press, Oxford.

Pawlak G, P MacCready, K Edwards \& R McCabe. 2003. Observations on the evolution of tidal vorticity at a stratified deep water headland. Geophysical Research Letters 30(24): 2234-2238. 
Ploug H, HP Grossart, F Azam \& BB Jorgensen. 1999. Photosynthesis, respiration, and carbon turnover in sinking marine snow from surface waters of Southern California Bight: implications for the carbon cycle in the ocean. Marine Ecology Progress Series 179: 1-11.

Poulin E, AT Palma, G Leiva, D Narváez, R Pacheco, SA Navarrete \& JC Castilla. 2002. Avoiding offshore transport of competent larvae during upwelling events: the case of gastropod Concholepas concholepas in Central Chile. Limnology and Oceanography 47: 1248-1255.

Roughan M, E Terrill, J Largier \& M Otero. 2005a. Observation of divergence and upwelling around Point Loma, California. Journal of Geophysical Research 110(C4) $<$ doi 10.1029/2004JC002662>

Roughan M, AJ Mace, J Largier, SG Morgan \& JL Fisher. 2005b. Subsurface recirculation and larval retention in the lee of small headland: A variation on the upwelling shadow theme. Journal of Geophysical Research 110(C10) <doi 10.1029/2005JC002898>

Signell RP \& WR Geyer. 1991. Transient eddy formation around headlands. Journal of Geophysical Research 96: 2561-2575.
Shanks AL \& A McCulloch. 2003. Topographically generated fronts, very nearshore oceanography and the distributions of chlorophyll, detritus, and selected diatom and dinoflagellated taxa. Marine Biology 143: 969-980.

Strickland JDH \& TR Parsons. 1972. A practical handbook of seawater analysis. Bulletin of the Fisheries Research Board of Canada 167: 1-310.

Vander Woude AJ, JL Largier \& RM Kudela. 2006. Nearshore retention of upwelled waters north and south of Point Reyes (northern California): Patterns of surface temperature and chlorophyll observed in CoOP WEST. Deep Sea Research II 53: 2985-2998.

Wing SR, LW Botsford, SV Ralston \& JL Largier. 1998. Meroplanktonic distribution and circulation in a coastal retention zone of northern California upwelling system. Limnology and Oceanography 43(7): 1710-1721.

York JK, Z Witek, S Labudda \& S Ochocki. 2001. Comparison of primary production and pelagic community respiration rates in the coastal zone of the Gulf of Gdansk. Oceanologia 43: 365-370.

Zar JH. 1999. Biostatistical analysis, 663 pp. Prentice-Hall, Englewood Cliffs.

Recibido el 23 de octubre de 2008 y aceptado el 7 de abril de 2009 